\title{
Nitrate in Sea-water and its Estimation by means of Diphenylbenzidine.
}

\author{
By \\ W. R. G. Atkins, F.I.C., F.R.S., \\ Head of the Department of General Physiology at the Plymouth Laboratory.
}

With 4 Figures in the Text.

\section{INTRODUCTION.}

Several methods have been used for the estimation of nitrate. First there stands the method employed by Raben and his co-workers and carried out in connection with Brandt's researches. This depends upon the reduction of the nitrate to ammonia, which is distilled off and nesslerised. These researches have been summarised by Brandt (1927). In the course of time a number of minor modifications tending to increase accuracy were made in the method, notably that of Buch (1923).

Gad-Andresen (1923) carried the reduction of ammonia a step further by means of alkaline sodium hypobromite, with liberation of free nitrogen, the volume of which was then measured. This method appears to give accurate results but is somewhat tedious. It was examined also by Orr (1926).

Harvey (1926) criticised these methods on the ground of their tediousness and of their being vitiated by a systematic error, which lowered their value, if it did not render them useless, in comparing the nitrate content of water which had been almost depleted of this constituent. The drastic method of reduction employed gives rise to ammonia from amino acids and possibly from proteid matter suspended in the water. Harvey applied to the analysis of nitrate in sea-water a colorimetric method introduced by Denigès as a test for bromine and subsequently used by him in 1911 as a test for nitrites and nitrates in water. This depends upon the oxidation of a reduced strychnine compound in sulphuric acid solution. The correct reduction product is not very easy to prepare and any method involving the use of strong sulphuric acid has certain obvious drawbacks and possible sources of error. Nevertheless, in Harvey's hands, this reagent has given good results whereby the changes in the English Channel have been studied throughout the year $(1926,1928)$. This method is well adapted for use in ships and rich results have been obtained 
by recent expeditions using it. At a meeting in Copenhagen in 1928 Brandt, Buch and Giral summarised the methods of estimating nitrogenous compounds in sea-water, and Harvey, Sund and Wattenberg gave their experiences using the reduced strychnine method. Gran (1930) published some of his results obtained in the North Sea with Klem and Braarud. Bigelow and Leslie also used the method in Monterey Bay in 1928. They report a difficulty in securing a suitable reagent. Moberg $(1928,1929)$ also used this method in the Pacific and introduced slight modifications. Ibañez (1929), too, made analyses by this method with water from off the Spanish coast. Wattenberg with Böhnecke and Hentschel obtained most interesting results in the open sea between Iceland and Greenland. Furthermore, Ruud (1930) investigated the nitrate content in the Antarctic, in the Weddell Sea, using reduced strychnine and the colorimeter devised by Sund. Kreps and Verjbinskaya (1930) also used the method in studying the Barents Sea in the Arctic. In addition to all these, it was used with conspicuous success by Helge Thomsen (1931) who worked with Sund's colorimeter and determined nitrates in the Atlantic, Mediterranean, Indian Ocean, Pacific Ocean as well as the seas around South China, the Celebes Sea, Sulu Sea and the Caribbean Sea. Thompson and Johnson (1930) comment on the difficulty in preparing the reagent and point out that any other oxidising material present in the water would also react with it ; in particular they mention iodate as giving a similar reaction. An accompanying paper in this Journal by Cooper considers the validity of the conclusions which led Thompson and Johnson to reject the method as being unreliable from the quantitative standpoint. It may however be pointed out that it seems to have been used quite successfully by a number of other workers who obtained results at least sufficiently accurate for their purpose. Bini (1929) apparently intended to use this method for examining the water of the Red Sea, but decided that it was not a convenient one to use on board ship; accordingly his column for nitrate is entirely filled with a succession of blanks. This does not however hinder him from putting forward the old theory that denitrifying bacteria are responsible for the low values of nitrate in the Red Sea. The theory that the absence of nitrate in tropical waters, or its presence in small quantities only, is due to the action of denitrifying bacteria appears to the writer to be at variance with the available evidence. From the action of denitrifying bacteria, in cultures rich in organic substances, the deduction has been made that these bacteria will act similarly in a dilute inorganic solution, such as sea-water, which is normally supersaturated with oxygen and provides no source of energy for this process. It is hard to see why bacteria should expend energy in taking oxygen from nitrate when there is already an ample supply of the gas dissolved in the water around them. Further- 
more, the consumption of nitrate nitrogen by fixed algæ and by diatoms can readily be demonstrated so that its absence in tropical waters can be looked on as due to its complete absorption by algæ in the well-illuminated upper regions. Again, the results of Thomsen, for the Mediterranean, show that the waters of this sea may be divided into seven regions. Working in the month of May he found an appreciable amount of nitrate in the surface waters of the third and fifth areas and little or none in any of the others except at one station in the first area. Phosphate on the other hand was found to be absent from the surface waters and down to very considerable depths, such as to 150 metres or more, in all or nearly all the stations examined. It is obvious therefore that the presence of nitrate, in the stations at which it was found, can be accounted for by the fact that, though nitrate and phosphate had both been brought up by vertical mixing in these regions, yet the phosphate supply had become exhausted; consequently plant growth could proceed no further and nitrate only remained in the surface water. As in the English Channel, it appears that the phosphate is the first to be exhausted and that as the season goes on nitrate becomes completely used up. This is due to the slow regeneration of phosphate which enables the nitrate to be taken up in the course of time.

Colorimetric methods have long been in use for the examination of the nitrate content of fresh water, notably the phenol (Sprengel, 1864) and cresol (Lindo, 1888) disulphonic acid and the carbazol (Hooker, 1888) methods. These are vitiated by presence of chloride, so obviously cannot be used in sea-water.

Another method based on the use of diphenylamine in sulphuric or acetic acid has been much used since introduced by Kopp (1872) and a large number of papers have been devoted to its examination.

The diphenylamine method was critically examined by Tillmans (1910) and he and Sutthoff (1911) applied it to the estimation of nitrates and nitrites in water. By the addition of sodium chloride to the reagent the degree of accuracy was increased, and they claim that results are uniformly obtainable to an accuracy of $0 \cdot 1 \mathrm{mg}$. nitric acid per litre. They state that nitrites, if present, react similarly to nitrates and combined determinations may be made. In sea-water it is desirable to make determinations not to 0.1 but to 0.001 milligrams of nitrate nitrogen per litre. As far as the writer is aware the diphenylamine method has been applied to the analysis of the nitrate content of sea-water only by Tschigirine and Daniltchenko (1930) in the Black Sea, for the peculiar conditions of which they obtained interesting results. The diphenylamine test is not of course a specific test for nitrates, like the phenoldisulphonic reaction. Ekkert (1925) examined a number of substances which might possibly give the reaction and found that it was given by nitrate, nitrite, chlorate, 
perchlorate, bromate, iodate, chromate, bichromate, molybdate, vanadate, ferricyanide and by hydrogen peroxide. None of these substances are, however, likely to interfere in the estimation of nitrate and nitrite in seawater, with the possible exception of iodate, which will be discussed later.

\section{The Diphenylbenzidine Test.}

In spite of the large number of papers devoted to its study since introduced by Kopp (1872) it was felt by Letts and Rea (1914) that the diphenylamine reaction was not entirely reliable. The probable course of the reaction has been studied by Kehrmann and Micewitz (1912) who pointed out that the diphenylamine was first of all reduced to tetraphenylhydrazine and that this became rearranged to give diphenylbenzidine. Further, the removal of hydrogen and the presence of sulphuric acid resulted in giving an imonium compound.

1. $2\left(\mathrm{C}_{6} \mathrm{H}_{5} \cdot \mathrm{NH} \cdot \mathrm{C}_{6} \mathrm{H}_{5}\right)-2 \mathrm{H}=\left(\mathrm{C}_{6} \mathrm{H}_{5}\right)_{2} \cdot \mathrm{N} \cdot \mathrm{N} \cdot\left(\mathrm{C}_{6} \mathrm{H}_{5}\right)_{2}$

2. $\left(\mathrm{C}_{6} \mathrm{H}_{5}\right)_{2} \cdot \mathrm{N} \cdot \mathrm{N} \cdot\left(\mathrm{C}_{6} \mathrm{H}_{5}\right)_{2}=\mathrm{C}_{6} \mathrm{H}_{5} \cdot \mathrm{NH} \cdot \mathrm{C}_{6} \mathrm{H}_{4} \cdot \mathrm{C}_{6} \mathrm{H}_{4} \cdot \mathrm{NH} \cdot \mathrm{C}_{6} \mathrm{H}_{5}$

3. $\mathrm{C}_{6} \mathrm{H}_{5} \cdot \mathrm{NH} \cdot \mathrm{C}_{6} \mathrm{H}_{4} \cdot \mathrm{C}_{6} \mathrm{H}_{4} \cdot \mathrm{NH} \cdot \mathrm{C}_{6} \mathrm{H}_{5}-2 \mathrm{H}+\mathrm{H}_{2} \mathrm{SO}_{4}=$

$$
\mathrm{C}_{6} \mathrm{H}_{5} \cdot \mathrm{N} \cdot \mathrm{C}_{6} \mathrm{H}_{4} \cdot \mathrm{C}_{6} \mathrm{H}_{4} \cdot \mathrm{NH}\left(\mathrm{C}_{6} \mathrm{H}_{5}\right) \cdot \mathrm{O} \cdot \mathrm{SO}_{3} \mathrm{H}
$$

Letts and Rea thought that the chances of this rather complex reaction going astray might be considerably lessened by starting with diphenylbenzidine instead of with diphenylamine. Wieland (1913) had prepared diphenylbenzidine, by oxidation of diphenylamine, in the course of his researches upon the production of the blue colour. Letts and Rea started with carefully purified diphenylbenzidine and found that the reaction depended on the temperature, the time and the proportions of the reagents. Their table gives results for nitrate nitrogen in water varying from 14.00 to $0 \cdot 10$ parts per 100,000 . The stronger solutions were diluted for estimation and comparisons were made in small crucibles. A colorimeter was not used. Nitrites, where present, were removed by means of potassium permanganate. Smith (1917) considered the diphenylbenzidine reaction to be about twice as sensitive as the diphenylamine reaction, in addition to being of greater reliability.

Preliminary tests on sea-water showed that the diphenylbenzidine reaction appeared to work well. Using sea-water and a dilute solution of the reagent in pure sulphuric acid it was found that, when the sea-water was diluted with an equal volume of distilled water, the ratio of the nitrate content of the diluted to the undiluted sea-water was $1: 1.70$ after 24 hours and $1: 1.91$ after 46 hours. Comparisons were carried out in a Kober colorimeter. Tests were made on a number of samples of sea-water which had been stored in the laboratory for some months. The results are shown in Table 1. The figures obtained by the use of diphenylbenzidine, shown 
in the column marked $\mathrm{A}$, indicate that the method is likely to give consistent results with sea-water. Indeed, the accord shown with the values obtained by the reduced strychnine method is remarkable. The actual amount of nitrate present in the $\mathrm{C}$ and $\mathrm{A}$ series cannot have been the same,

\section{TABLE 1.}

Comparisons of Nitrate found in Sea-Water at International Hydrographic Station El on various Dates, taking the $70 \mathrm{M}$. Values as 100 per cent for each Water Column.

The values under $\mathrm{C}$ are those kindly supplied by L. H. N. Cooper, from his own analyses (see accompanying paper) by the reduced strychnine method, carried out on preserved samples. Under A are shown those obtained using the diphenylbenzidine method; the samples were stored in semi-darkness, without preservative, till mid-October, 1931.

\begin{tabular}{rrrrrrr} 
& \multicolumn{2}{c}{ April 7. } & \multicolumn{2}{c}{ April 22. } & \multicolumn{2}{c}{ May 18. } \\
$\mathrm{m}$ & $\mathrm{C}$ & $\mathrm{A}$ & $\mathrm{C}$ & $\mathrm{A}$ & $\mathrm{C}$ & $\mathrm{A}$ \\
0 & - & - & 100 & 107 & 25 & 122 \\
5 & 106 & 98 & 80 & 80 & 100 & 108 \\
10 & 85 & 88 & 80 & 77 & 100 & 102 \\
15 & - & - & 95 & 97 & 100 & $(59)$ \\
25 & - & - & 105 & 95 & 137 & 103 \\
50 & - & - & 88 & 98 & 150 & 102 \\
70 & 100 & 100 & 100 & 100 & 100 & 100
\end{tabular}

so it seems that regeneration of nitrate must have proceeded in the A series in a manner roughly proportional to the amount of nitrate originally present. This is very remarkable, in view of the results of Issatchenko (1926), for he failed to find nitrate producing bacteria in the water column except near the bottom. It appears, however, that in our samples a certain measure of nitrate regeneration has proceeded throughout the column, since the absolute amounts found under the heading $\mathrm{A}$ are greater than those under C, as shown by later work. This point must be left over for future investigation. It remains to consider the conditions necessary to obtain the best results when the reaction is carried out in sea-water.

\section{Proportions of Water and Reagent.}

Letts and Rea recommend that the reaction should be carried out by taking $0.5 \mathrm{ml}$. of solution and adding to it $1.2 \mathrm{ml}$. of pure concentrated sulphuric acid. Heat is developed, but before adding diphenylbenzidine the mixture is allowed to cool down to room temperature. When cool 
$0 \cdot 3 \mathrm{ml}$. of a solution of diphenylbenzidine in concentrated sulphuric acid is added and the colour produced is examined after a few minutes and again after an hour or more. To study this point a series of quartz test tubes were taken and to them $1.00 \mathrm{ml}$. of a solution containing $0.001 \mathrm{mg}$. of nitrate nitrogen was added. Water, which had been previously distilled, was redistilled from barium hydroxide through a glass condenser and accurately-measured small volumes were added to dilute the $1 \mathrm{ml}$. already in the tube. Pure sulphuric acid containing diphenylbenzidine was then run in to make a total volume of $11.0 \mathrm{ml}$. in each case. Figure 1

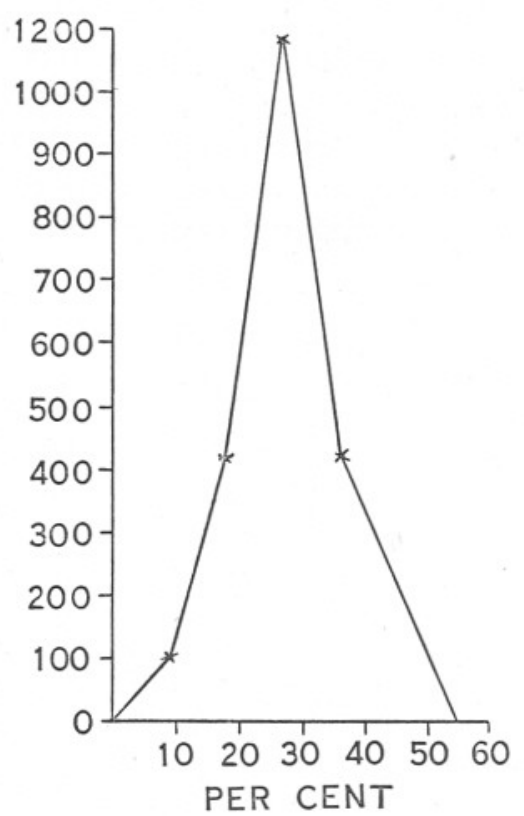

FIG. 1.-The abscissæ denote percentages of water, by volume, in the sulphuric acid mixtures. The ordinates are arbitrary colour units. The nitrate concentration was constant throughout.

shows the intensity of colour in relation to percentage of water by volume. The maximum was found with the proportion of 3 of water to 8 of pure acid, by volume, which is equivalent to $27 \cdot 3$ per cent. Such a mixture gives the greatest evolution of heat. This is close to the value $25 \%$ recommended by Letts and Rea. It may be noted how sharply production of colour falls off once the maximum has been passed. This appears to be due to the dissociation of the sulphuric acid imonium compound shown in the equation already given. It was thought at first that, instead of using a colorimeter, it might be possible to titrate back this oxidised 
substance using a reducing reagent such as a sulphide or titanous chloride. This however was found to be impossible owing to the large effect exerted on the colour by dilution with water alone. The proportions recommended by Letts and Rea were adopted for use in sea-water, the actual volumes being five times as great.

\section{The Concentration of the Diphenylbenzidine Sulphuric Acid Reagent.}

Table 2 shows the concentration of diphenylbenzidine used by various workers.

\section{TABLE 2.}

\section{Effect of Concentration of Diphenylbenzidine upon the Intensity of Colour Produced in the Reaction.}

With $0.001 \mathrm{mg}$. nitrate nitrogen per tube, $2.5 \mathrm{ml}$. water $+6.0 \mathrm{ml}$. acid + $1.5 \mathrm{ml}$. acid reagent.

\begin{tabular}{|c|c|c|c|c|}
\hline \multirow{2}{*}{\multicolumn{2}{|c|}{$\begin{array}{c}\text { Grams per } \\
100 \mathrm{ml} \text {. of } \mathrm{H}_{2} \mathrm{SO}_{4} \text {. }\end{array}$}} & \multicolumn{3}{|c|}{ Time since mixing. } \\
\hline & & $1.5 \mathrm{hrs}$. & 25 hrs. & 9 days. \\
\hline $0 \cdot 004$ & Atkins & 100 & 100 & Blue, paler on top. \\
\hline $0 \cdot 020$ & Letts and Rea & 200 & 254 & $\begin{array}{l}\text { Blue at bottom, yellow half- } \\
\text { way down with brownish } \\
\text { precipitate. }\end{array}$ \\
\hline $0 \cdot 100$ & Snell & 205 & $74^{*}$ & Light green, no precipitate. \\
\hline $1 \cdot 000$ & Yoe & - & - & - \\
\hline
\end{tabular}

It is obvious that the concentration of $20 \mathrm{mg}$. per $100 \mathrm{ml}$. of acid is sufficient for dilute solutions to attain the maximum speed of reaction without undue loss of stability.

According to Kolthoff and Sarver (1930) the green colour produced with Snell's proportions is due to the combination of the blue salt with the excess of diphenylbenzidine.

\section{Relation between Colour Intensity and Nitrate Concentration.}

A series of tubes was made up containing distilled water, acid and acid reagent in the proportions shown in Table 2. The series consisted of tubes containing $0,10,20$ and $40 \mathrm{mg}$. per cubic metre of added nitrate nitrogen. The depth of colour produced after 21 hours is shown in Figure 2. The ordinates are colour units, taking that produced by the $20 \mathrm{mg}$. tube as 100. It will be noticed that a certain amount of colour is given by distilled water, owing to the traces of nitrate in it and to the nitrate present

\footnotetext{
* Colour distinctly green.
} 
in sulphuric acid. By producing the curve backwards, so as to cut the concentration axis, it may be seen that the distilled water and acid between them produced a concentration of $27 \mathrm{mg}$. of nitrate nitrogen per $\mathrm{m}^{3}$.

In Figure 3 the same process has been repeated, using sea-water which had been stored in a large carboy for some months, so that all sediment had settled out of it. This was found to contain only a minute trace of nitrite, less than $1 \mathrm{mg}$. per $\mathrm{m}^{3}$ of nitrite nitrogen. The colour produced by the sea-water with $40 \mathrm{mg}$. has been taken as giving 100 colour units. It may

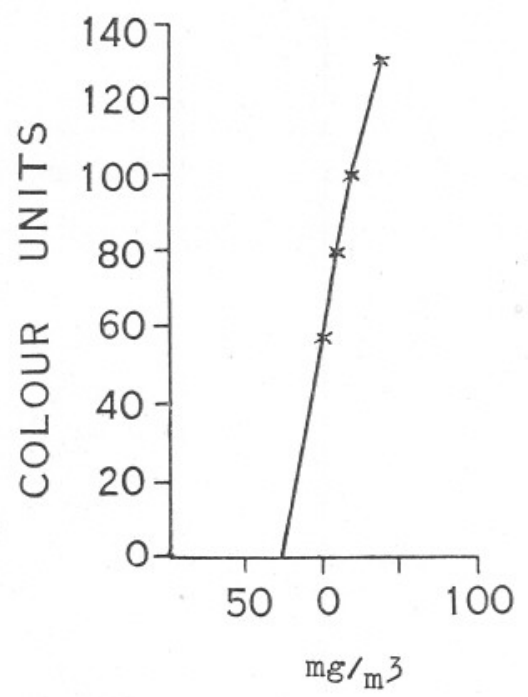

FIG. 2.-The concentration of added nitrate nitrogen in the distilled water is shown by the abscissæ, read from 0 towards the right. The concentration resulting from that originally in the water, as increased by the sulphuric acid, may be read off towards the left.

be seen that the more concentrated solutions depart from the linear relationship, though it was found that on allowing to stand for 44 hours the curve became straighter at the greater concentrations, though still not a straight line; for obvious reasons it seemed desirable to limit the time of standing for comparing the tubes to about 20 hours. It may be seen from Figure 3 that the sea-water tubes contain $75 \mathrm{mg}$. per $\mathrm{m}^{3}$, not correcting for the amount of nitrate in the acid. Separate determinations in which acid was substituted for distilled water or sea-water showed that the concentration in the sulphuric acid was about $7 \mathrm{mg}$. of nitrate nitrogen per $\mathrm{m}^{3}$. When correction for this has been made according to the method 
previously described (Atkins, 1930), the sea-water was found to contain $72.5 \mathrm{mg}$. per $\mathrm{m}^{3}$. It is not of course claimed that the decimal place is of any real significance.

\section{The Degree of Accuracy Obtainable.}

Much time was expended in trying to get results which were of a reasonably high degree of accuracy, and the variations between tubes prepared

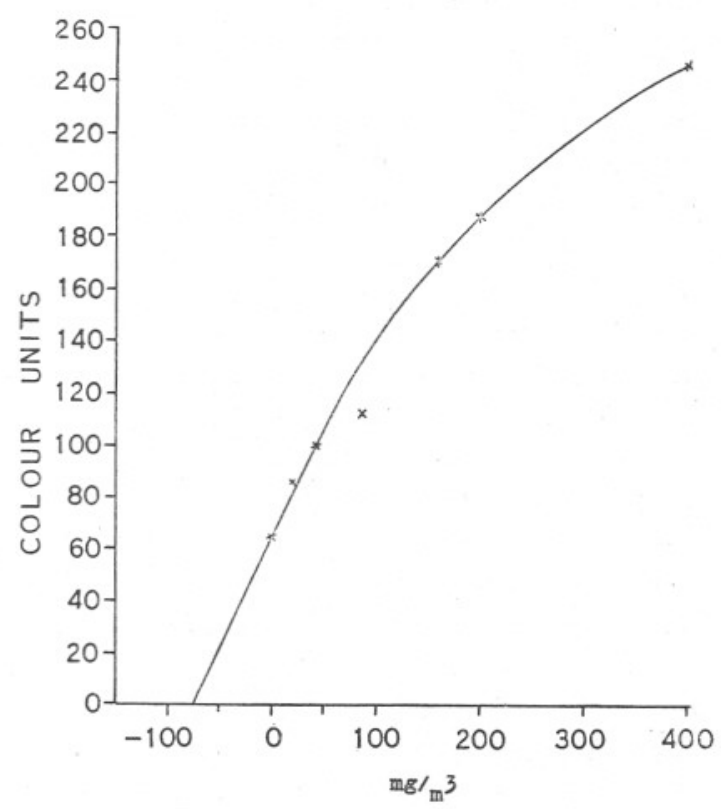

FIG. 3.-The concentration of added nitrate nitrogen in a sample of sea-water is shown by the abscissæ, read from 0 towards the right. The concentration resulting from that originally in the water, as increased by the sulphuric acid, may be read off towards the left.

in an apparently identical manner were found, at the outset, to be very baffling.

First of all, one must use pure sulphuric acid, such as the nitrogen-free product supplied by the British Drug Houses Ltd. This acid was only produced by the firm after it had been reported to them that the acid supplied as pure sulphuric acid really contained considerable quantities of nitric acid. No better success had attended the use of foreign and other British acids (Harvey, 1926). Even the "Arsenic Test" sulphuric acid (B.D.H.) was liable to contain appreciable amounts of nitrate nitrogen. 
The nitrogen-free acid at present being supplied is exceptionally good and gives no colour after standing with the reagent for a day, or gives only very slight colour. The latter indeed is to be preferred, since the absence of all colour leaves one in doubt as to whether the acid may not have a slight reducing action.

It has been found by the writer (1932) that even sulphuric acid, which gives a marked reaction for nitrate, can be entirely freed by the cautious addition of ammonium sulphide or preferably of hydrogen sulphide. This leaves only a minute amount of sulphur, too small to produce a turbidity, and the quantity used should be adjusted so that the reagent still produces a very faint colour with the acid.

A number of samples of distilled water were compared and it was found that in general our laboratory supply could be used. The Plymouth town supply is a very pure upland water and the laboratory where analyses were carried out is free from the fumes usually present in a chemical laboratory. Moreover, owing to the prevailing winds blowing in from over the sea, it is only rarely that the atmosphere is contaminated by nitrogen acid fumes, though this happens occasionally when the wind is from the east. Freshly prepared laboratory-supply distilled water from a hard glass bottle, used for years only for distilled water, was compared with the same water specially redistilled from a glass vessel containing barium hydroxide. The distillation was carried out in a room from which all nitric acid bottles had been removed some months previously, no flames were burning in the room and distillation was effected by means of an electric hot plate, while a sea breeze was blowing through the room. When these samples of distilled water were treated as usual and the resulting $10 \mathrm{ml}$. mixtures were compared in quartz tubes after standing for one day, it was just possible to distinguish them. The laboratory distilled water gave a tint to which it was impossible to ascribe a definite colour, but in the case of the water distilled from the barium hydroxide and from the hot plate no suspicion of a tint could be seen. It was found, however, that on standing in a laboratory, in the absence of bottles of nitric acid, but in which flames were occasionally burning, both the distilled water and the sulphuric acid were liable to absorb a trace of nitric or nitrous acid.

Great care must be taken in cleaning all the vessels used, with pure strong sulphuric acid; white glass, especially optical glass used in colorimeters, is liable to give off very considerable amounts of nitrate.

Though the colour production is most intense when the acid reagent is added directly to the sea-water, so that the mixture becomes very hot, yet it is impossible to control the temperature with any success owing to differences in the rate of adding the acid and differences in the thicknesses of the walls of the test tubes used. Accordingly Letts and Rea recommend 
that the water and sulphuric acid should first of all be mixed and allowed to stand till room temperature has been reached, and after that the reagent should be added in another quantity of acid. This subsequent addition results in only a very slight evolution of heat. The mixing is carried out as follows: The sea-water is first of all added to the carefully cleaned quartz tubes (glass may also be used), then the pure sulphuric acid is run in, attention being paid to the times of delivery being closely the same in these additions, so that the loss of acid on the sides of the burette, owing to the viscosity of the sulphuric acid, may be the same in each case.

It is necessary when dissolving diphenylbenzidine in sulphuric acid to stir the mixture extremely thoroughly. Unless this is done quite appreciable differences in concentration may exist when the solution is poured into the burette. It is necessary to mix very carefully, with a rod, the contents of the tubes after the addition of the acid to the reagent. Even after what had appeared to be an adequate amount of stirring, it was found on occasion that the colour developed unevenly.

As previously remarked the presence of flames in the room is to be avoided and all risk of contamination by floating dust particles should be reduced to a minimum. Apparently minute particles of dust may either contain nitrates or conversely may reduce sulphuric acid so that nitrate present in the mixture is lost.

When using sea-water it is essential, unless the bottles have stood for a considerable time, to centrifuge so that all plankton organisms may be thrown down. This modification, introduced into Harvey's method by Cooper, is a very necessary one in plankton-rich water.

Having taken all precautions mentioned and having executed each operation with the greatest care, erratic results are still obtained occasionally. Thus, when a series of tubes had been examined in the colorimeter after 20 hours, and had been kept for 24 hours more, it was found that one tube which formerly gave a value rather lower than the average had increased to a more normal value. In that case apparently the reaction had been delayed, either by this tube having been slightly cooler than the others at the start, or by inadequate mixing. On the other hand, one tube which gave quite a normal value after 20 hours gave a decidedly high result after the further period of standing. This can only be explained by some chance contamination.

In Table 3 are shown the results of a series in which all precautions were taken. It may be seen that the divergence from a mean value is about $5 \%$ for the shorter period of standing. On the amount of nitrate nitrogen present, however, this only amounts to $10^{-8}$ of a gram. Errors in measuring out three small volumes are of course included in this figure.

NEW SERIES,-VOL. XVIII. NO. 1. MAY, 1932. 


\section{TABLE 3.}

To Show Degree of Accord Obtainable.

Six tubes taken, each with $2.50 \mathrm{ml}$. of centrifuged sea-water containing $72 \mathrm{mg}$. per $\mathrm{m}^{3}$ of nitrate nitrogen, $6.00 \mathrm{ml}$. of pure sulphuric acid added and when cold $1.50 \mathrm{ml}$. of acid reagent. The cups were each reversed in the colorimeter and the mean values of right and left are given. The amount being analysed is $0 \cdot 000,18 \mathrm{mg}$., so 5 per cent error is $0 \cdot 000,01$ approx.

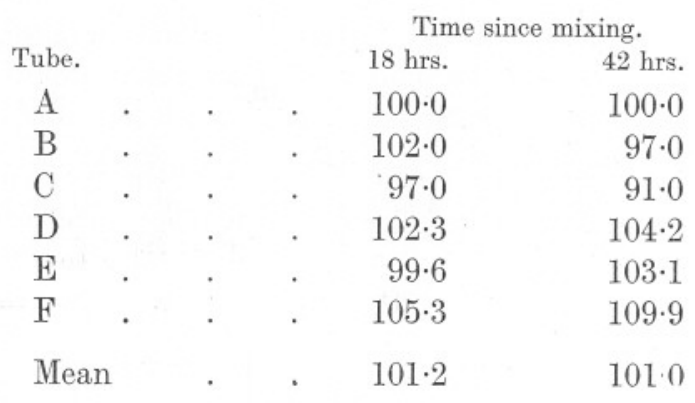

\section{Effect of Sodium Chloride on the Reaction.}

Tillmans showed that the addition of sodium chloride to the diphenylamine reaction led to an increase in the intensity of colour. It must obviously have the same effect on the diphenylbenzidine reaction.

Table 4 shows the results obtained with a series of tubes. It appears, therefore, that one could make up a set of standards containing known amounts of nitrate nitrogen dissolved in a solution made to be $0.4 \%$ with sodium chloride. On account however of a possible reducing action of traces of organic matter in the sea-water, it is preferable to use sea-water to which known amounts of nitrate have been added.

\section{TABLE 4.}

\section{Effect of Sodium Chloride upon the Intensity of Colour Produced in the Reaction.}

Each tube had $0.001 \mathrm{mg}$. of nitrate nitrogen in $2.5 \mathrm{ml}$. of water or salt solution $+6.0 \mathrm{ml}$. of $\mathrm{H}_{2} \mathrm{SO}_{4}$ and when cold $1.5 \mathrm{ml}$. of diphenylbenzidine sulphuric acid reagent. The tube without chloride is taken as 100 in each case ; obviously the colour in the 69 -hr. tube was the greater, but variation with time is not being considered here. 


\begin{tabular}{clcc}
$\begin{array}{c}\text { NaCl per cent } \\
\text { in water. }\end{array}$ & \multicolumn{1}{c}{ Time since mixing, in hours. } & & \\
$0 \cdot 5$ & 100 & 69 \\
$0 \cdot 0$ & Deepest colour* & 113 & 100 \\
$0 \cdot 2$ & Less colour & 121 & 133 \\
$0 \cdot 4$ & " again & 121 & 131 \\
$1 \cdot 0$ & " again & 121 & 129 \\
$2 \cdot 0$ & " again & 121 & 129 \\
$3 \cdot 0$ & Least save control & $7 \cdot 6$ & $6 \cdot 2$ \\
$3 \cdot 0 \dagger$ & Very slight blue & &
\end{tabular}

\section{Effect of Iron Salts upon the Reaction.}

With regard to the action of iron preliminary experiments were carried out at the very start of this investigation using $1 \mathrm{ml}$. of solution to 10 of the acid reagent. The heat developed on mixing them was of course considerable. Ferric chloride solutions of the concentration $\mathrm{m} / 10^{2}$ and $\mathrm{m} / 10^{4}$ were used. Neither gave any more colour than that obtained with distilled water and acid alone. It is probable, however, that the ferric

\section{TABLE 5 .}

\section{Comparison of Effect of Nitrate, Nitrite and Ferric Iron upon the Intensity of Colour Produced.}

Mixtures $0.001 \mathrm{mg}$. nitrate nitrogen, $0.001 \mathrm{mg}$. nitrite nitrogen and $\mathrm{M} / 10,000 \mathrm{Fe}$ (ic) chloride, $1.0 \mathrm{ml}$, viz. $0.0056 \mathrm{mg}$. Fe in $2.5 \mathrm{ml}$. water. Examined after 20 hrs.

(a) Nitrate, allowed to cool after acid, then acid reagent 100

(b) Nitrite , " , , , , , , ,

(c) , " , $\quad, \quad, \quad, \quad, \quad 71 \cdot 2$

(d) , cooled广 under tap, then acid reagent $\quad 71 \cdot 2$

(e) , , , , , , $\quad 69.9$

(f) Iron, allowed to cool, then acid reagent $\quad 26 \cdot 6$

(g) , ", ", $, \quad, 27 \cdot 0$

(h) Acid blank, no heat developed $4 \cdot 4$

chloride was reduced by the strong hot sulphuric acid, so the experiments were repeated in the cold using the normal proportions and the results are shown in Table 5. From these it may be seen that ferric iron is about 21 times less effective, weight for weight, than nitrate nitrogen. Since it has been shown by Harvey (1925) that no ferric iron is present in sea-water

\footnotetext{
* This was the last tube to be mixed, and so had stood a lesser time than the others.

$\dagger$ Control with no added nitrate.

† The cooling was done after acid had been added to the other tubes also.
} 
and that only small amounts of iron in any condition are normally found, it appears obvious that no error from the presence of iron can be expected in coastal waters. It is, however, just possible that in the great ocean depths there may be small amounts of interference due to the possible presence of iron in a ferric state and in concentration much greater than normally found in shallower seas. Ferrous salts gave no colour with the reagent.

\section{The Reaction with Nitrite.}

According to Tillmans and Sutthoff (1911) the action of nitrate and nitrite is similar, so that combined determinations may be made using diphenylamine. The same should be true starting with diphenylbenzidine, so that the use of permanganate by Letts and Rea to remove nitrite, as such, seems unnecessary, and risky too, since permanganate itself gives the reaction. It is known however that free nitrous acid is decomposed on heating, and much heat is developed when the sulphuric acid is added. Table 5 shows that in the reaction, as ordinarily carried out, about 30 per cent of the nitrous acid is destroyed. From Table 6 it may be

\section{TABLE 6 .}

Comparison of Effect of Nitrate and Nitrate, as in Table 5.

(a) Nitrate, allowed to cool, then acid reagent

(b)

$(c)$

(d) Nitrite, cooled at once under tap, then acid reagent

(e) Nitrite, allowed to cool, then acid reagent

(f) , stood in boiling* water a few minutes, then acid reagent

$\begin{array}{cc}20 \text { hrs. } & 44 \text { hrs. } \\ 100 & 100 \\ 101 & - \\ 108 & - \\ & \\ 106 & 106 \\ 65 & 61 \\ & \\ 66 & 61\end{array}$

seen that if the tube be cooled at once this loss of nitrous acid may be prevented or much reduced. Even with some additional heating the destruction does not amount to the theoretical value according to the equation :-

$$
3 \mathrm{HNO}_{2}=\mathrm{HNO}_{3}+2 \mathrm{NO}+\mathrm{H}_{2} \mathrm{O} \text {. }
$$

As however the amount of nitrite in sea-water is normally small the loss is not of much practical importance, but with high nitrite-as much as $38 \mathrm{mg}$. nitrite nitrogen per $\mathrm{m}^{3}$ has been found (Atkins, 1930)-the tubes should be cooled immediately.

* The beaker was removed from the flame, to avoid contamination from that source. The temperature was therefore rapidly falling. 


\section{The Possible Interference of Iodide, Iodate, Arsenite and Arsenate.}

Sea-water is known to contain iodide, which with strong sulphuric acid liberates hydriodic acid. It appeared possible that this might act as a reducing agent and so lessen the production of colour due to nitrate. It has been shown by Reith (1930) that there is in sea-water about $43 \mathrm{mg}$. per $\mathrm{m}^{3}$ of total inorganic iodine, corresponding to a normality of $0 \cdot 34 \times$ $10^{-6}$. Potassium iodide was accordingly made up in $\mathrm{m} / 10^{3}$ concentration and diluted in successive steps of ten times down to $\mathrm{m} / 10^{6}$. These four dilutions were prepared with laboratory distilled water and it was found that the most concentrated solution gave a bright yellow due to the liberation of iodine. The other three gave scarcely any more blue than the blank. The fact that they did give a very faint blue in excess of that given by the blank is probably due to the presence of a trace of iodate. Had the iodide, sar rather the free hydriodic acid, exerted any reducing action, the tubes should of course have been perfectly colourless. This possible reducing action was further tested by mixing equal volumes of these iodide solutions, from $\mathrm{m} / 10^{4}$ to $\mathrm{m} / 10^{6}$, with a solution containing $0.001 \mathrm{mg}$. of nitrate nitrogen per $\mathrm{ml}$. A highly concordant series was obtained in which no difference could be seen between the tubes containing nitrate and those with nitrate and added iodide.

As already mentioned, Thompson and Johnson pointed out that iodate also gave the reaction with the reduced strychnine reagent. Cooper, in an accompanying paper, has shown that this reaction, though given, is very much less sensitive, so that $4000 \mathrm{mg}$. per $\mathrm{m}^{3}$ of iodine as iodate produce only as much colour as $3 \mathrm{mg}$. of nitrate nitrogen. That is to say that iodate may be entirely neglected, even if present, in making an estimation by this method. As regards the presence of iodate, Winkler (1916) found a sample of sea-water from the Adriatic to contain $38 \mathrm{mg}$. per $\mathrm{m}^{3}$ total iodine, of which the iodide ion accounted only for $8 \mathrm{mg}$. and iodate the remainder, there being no organically bound iodine. Correcting to normal salinity the total iodine came to $51 \mathrm{mg}$.

It was found that with the diphenylbenzidine reagent nitrate and iodate behaved identically, using equivalent proportions, namely, $\mathrm{m} / 10^{3}, \mathrm{~m} / 10^{5}$ and $\mathrm{m} / 10^{6}$. Consequently it seems that iodate present in sea-water will be recorded as nitrate. Nevertheless, when a comparison was made between the two methods of analysis, Cooper obtained, for samples from Station E1, taken on October 20th, $27 \mathrm{mg}$. nitrate nitrogen per $\mathrm{m}^{3}$ for the surface water and $29 \mathrm{mg}$. as an average for $0,5,25,50$ and $70 \mathrm{~m}$., whereas the diphenylbenzidine method gave $28 \mathrm{mg}$. for the surface and $31.5 \mathrm{mg}$. from samples of the whole water column mixed together. The 
agreement is very close, and it appears to rule out the presence of iodate in this sample of sea-water in any significant quantity.

To reduce iodate to iodide Winkler added $5 \mathrm{ml}$. N/100 $\mathrm{As}_{2} \mathrm{O}_{3}$ solution and $10 \mathrm{ml}$. strong hydrochloric acid to each litre of sea-water and allowed to stand for half an hour. To effect the same object Reith used, for each $500 \mathrm{ml}$. of filtered sea-water, $100 \mathrm{mg}$. of sodium hydrogen sulphite and $5 \mathrm{ml}$. iodide free $4 \mathrm{~N}$ hydrochloric acid and allowed a few minutes only for the reaction.

Before studying the effect of these reagents upon the diphenylbenzidine reaction with iodate, it is advisable to consider their behaviour separately. Arsenic is known to exist in sea-water, as much as $25 \mathrm{mg}$. per $\mathrm{m}^{3}$, reckoned as $\mathrm{As}_{2} \mathrm{O}_{3}$, having been found by the Government Chemist (Orton, 1924) in water from the English Channel in November. It has further been shown by Atkins and Wilson (1927) that most, if not all, of this exists in the form of arsenite.

Ekkert's list of substances giving the diphenylamine (and consequently diphenylbenzidine) reaction does not mention arsenate. On testing solutions of arsenic acid the blue colour was always produced. By varying the concentration, however, it was proved that the colour was not due to arsenic acid but to some impurity, bearing no constant ratio to arsenic from sample to sample. It is obvious, therefore, that the arsenate, if any, present in sea-water, is without effect upon the estimation of nitrate.

To test the effect of arsenious acid six tubes were prepared. A, B and $\mathrm{C}$ contained each $1.0 \mathrm{ml}$. of $\mathrm{m} / 10^{3} \mathrm{KNO}_{3}$, and $\mathrm{D}, \mathrm{E}, \mathrm{F}$ a corresponding amount of $\mathrm{KIO}_{3}$. A and $\mathrm{D}$ received each $2.0 \mathrm{ml}$. of water, and $\mathrm{C}$ and $\mathrm{F}$ the same volume of a solution of $\mathrm{As}_{2} \mathrm{O}_{3}$ containing $70 \mathrm{mg}$. per litre. B and $\mathrm{E}$ received each $1.0 \mathrm{ml}$. of water and $1.0 \mathrm{ml}$. of arsenious solution. After standing with acid for about $2 \frac{1}{2}$ hours the reagent was added. The nitrate tubes were absolutely unaffected by the arsenious acid. The iodate tubes showed slight reduction, amounting to 7 per cent for F. Obviously a greater concentration of arsenious oxide is required, and the amount present in the sea would thus appear to be quite without effect upon the nitrate reaction.

Tubes were similarly treated, adding to each, instead of arsenious acid, solid sodium hydrogen sulphite the size of a pin's head. The nitrate remained unaffected, but the iodate was almost completely destroyed, the colour produced being only about one-third again as intense as the blank with distilled water.

On testing with sea-water, however, it was found that the addition of a larger amount of solid sodium hydrogen sulphite did bring about an appreciable reduction of nitrate, though the addition to each tube of traces of the solid was without effect. By "traces" is meant an amount 
which was just visible on the end of a knife ; this is, however, a very large excess as regards the minute amount of nitrate.

The reaction was then tried on two samples of sea-water, one stored for ten months, the other freshly drawn. To the usual $2.5 \mathrm{ml}$. was added $1.0 \mathrm{ml}$. of $\mathrm{m} / 10^{5}$ sodium hydrogen sulphite and $1.0 \mathrm{ml}$. of $\mathrm{m} / 10^{3}$ solution. On adding the usual reagents it was found that no reduction had been effected by the $\mathrm{m} / 10^{5}$ solution, but that the $\mathrm{m} / 10^{3}$ solution had reduced the nitrate - or nitrate plus iodate - to about one-third.

Iodate alone was then tried with $\mathrm{m} / 10^{5}$ solution. Since the total iodine present is probably not far from $0 \cdot 34 \times 10^{-6}$ normal, using $2.5 \mathrm{ml}$. of iodate and $1.0 \mathrm{ml}$. of sulphite, solutions should leave the latter in excess. On proceeding with the reaction it was found that 25 per cent of the iodate had been destroyed. Obviously sufficient time had not elapsed for the reaction to become completed; only the usual cooling time had been allowed. It would appear advisable, therefore, to treat the water with the reducing reagent and to acidify slightly, so that Reith's method for removal of iodate may be allowed to proceed to completion before the full amount of sulphuric acid is added. The fact that no reduction was effected in the two samples of sea-water by adding the $\mathrm{m} / 10^{5}$ solution of reducing agent, whereas this reduced a pure iodate solution, appears to indicate that in these samples iodate was not present in any appreciable quantity; this seems the more likely since the reagent is more active in reducing nitrate in sea-water than in fresh, owing doubtless to the chloride, which interferes as in the permanganate and other oxidations.

There is, however, another reason to account for the small effect produced by the iodate known to be present in sea-water. The following reactions must be considered :-

(a) $3 \mathrm{I}_{2}+6 \mathrm{KOH}=5 \mathrm{KI}+\mathrm{KIO}_{3}+3 \mathrm{H}_{2} \mathrm{O}$.

(b) $\mathrm{HIO}_{3}+5 \mathrm{HI}=3 \mathrm{I}_{2}+3 \mathrm{H}_{2} \mathrm{O}$.

Thus it may be seen from $(a)$ that iodine set free in an alkaline solution, such as sea-water, reverts to iodate to the extent of one-sixth. Further oxidation may of course increase the amount, but the ratio iodite-iodate in sea-water does not appear to have been adequately studied. On acidifying sea-water, however, as is done in the diphenylbenzidine reaction, the iodate present is destroyed by the iodide; only the excess of the iodate, if there is any, will be left to simulate nitrate. This was tested as follows: To each of two tubes $1.0 \mathrm{ml}$. of $\mathrm{m} / 10^{4}$ potassium iodate was added; then the first received $1.0 \mathrm{ml}$. of water and the second $1.0 \mathrm{ml}$. of $\mathrm{m} / 10^{3}$ potassium iodide, the molecular ratio being accordingly $1: 10$, a good excess over the required $1: 5$. On completing the test as usual the first tube gave the usual deep blue, the second only a light colour due to the pink of the iodine in strong acid, the blue of the blank, 
and perhaps slightly more. The colours could not be matched. The iodate has been destroyed by the excess iodide.

Two tubes were then prepared similarly save that $\mathrm{m} / 10^{5}$ iodate was used and $\mathrm{m} / 10^{4}$ iodide. At this dilution the reaction between iodide and iodate does not appear to proceed, the colorimeter readings being almost identical.

With sea-water, however, the reaction does appear to take place (cp. the difference also in the sodium hydrogen sulphite reaction in seawater), for when two tubes containing $1.0 \mathrm{ml}$. of sea-water received respectively $1.0 \mathrm{ml}$. of water and of $\mathrm{m} / 10^{4}$ potassium iodide, the blue colour given by the untreated sea-water was the more intense, in the approximate ratio $10: 9$. Since it contained $72.5 \mathrm{mg} . / \mathrm{m}^{3}$ nitrate nitrogen, including iodate, the corrected value becomes $67.5 \mathrm{mg} / \mathrm{m}^{3}$. It should be noted that the excess of potassium iodide used here was very great, $1.0 \mathrm{ml}$. of $\mathrm{m} / 10^{4}$, whereas the total iodine is only about $0 \cdot 34 \mathrm{~m} / 10^{6}$. A considerable excess appears to $\mathrm{b} 6$ needed, as even in sea-water $1 \mathrm{ml}$. of $\mathrm{m} / 10^{4}$ iodide did nớ completely destroy $1 \mathrm{ml}$. of $\mathrm{m} / 10^{5}$ iodate.

It remains to consider the possible effect of the iodine liberated according to equation $(b)$ upon the course of the diphenylbenzidine reaction. Tubes were made up containing $1.0 \mathrm{ml}$. of $\mathrm{m} / 10^{5}$ potassium nitrate with $1.0 \mathrm{ml}$. of water, $1.0 \mathrm{ml}$. of $\mathrm{n} / 10^{5}$ iodine with water as before and $1.0 \mathrm{ml}$. of each solution. On completing the reaction as usual the nitrate solutions gave an intense blue, the iodine solutions gave a light blue, with a faint pink shade, and the mixture gave an approximately additive result. The iodine therefore does not seriously interfere with the reaction even when present in a far greater amount than in sea-water, viz. $\mathrm{n} / 10^{5}$ as against less than $n / 10^{6}$. The use of the potassium iodide method of destroying iodate seems to be quite legitimate.

\section{Effect of Miscellaneous Reagents on the Reaction.}

When at the start trouble was experienced with the presence of traces of nitric in the sulphuric acid an attempt was made to use phosphoric acid instead of sulphuric acid. Glacial acetic acid has been used in the diphenylamine reaction, but the reaction does not then seem to be as sensitive as when sulphuric acid is used. It was found that syrupy phosphoric acid gave no trace of blue colour with the diphenylbenzidine, but on the addition of a trace of nitrate an intense blue was produced. It can be used in testing fresh water, though no experiments have been carried out to see whether it is quite as delicate as when using sulphuric acid. With sea-water, however, a precipitate is given with phosphoric acid. An attempt was made to remove the calcium and magnesium in the sea-water by adding phosphate, and the supernatant liquid was then used for the test; it was found, however, that a precipitate was still produced, due apparently to the sulphate and possibly chloride. It was 
unnecessary to seek farther because sulphuric acid sufficiently pure was then obtained. It was found, moreover, if a light blue colour was produced when the reagent was mixed with sulphuric acid, that this could be completely destroyed by gently warming the mixture. Acid grossly contaminated with nitric acid however, though the colour became slightly paler on heating, still gave an intense blue.

As previously mentioned the blue colour is given with ferric salts. An attempt was made to avoid this by the use of small quantities of citric acid; this however only delayed the onset of the blue, and the citric acid was soon decomposed by the strong sulphuric acid. It was found that the blue colour produced in the reaction could be decolorised by the addition of ferrous sulphate, which however leaves a white turbidity. Ammonium sulphide vapour though effective in preventing the formation of the blue compound, if added before the reagent, does not decolorise it when added subsequently. It was also found that potassium permanganate, potassium chromate, bichromate and ferricyanide gave the reaction, but not potassium ferrocyanide, which however does not destroy the blue colour once it has been formed, and may give a white turbidity. It is, of course, obvious that all the reagents which give the blue colour with the diphenylamine reagent will also give it with diphenylbenzidine.

\section{Stability towards Light.}

The red colour given by the reduced strychnine reaction is unstable towards light, even towards the diffuse daylight of the laboratory, and special precautions have to be taken to protect it. It was found, on the

\section{TABLE 7.}

Stability towards Light and Exposure to Air.

Three tubes were prepared and examined after three hours. They were then treated as follows :-

After $3 \mathrm{hrs}$.

(a) 100 Rubber cap and kept in dark

(b) 106 Do. but in south window*

$\begin{array}{cc}4 \text { days. } & 11 \text { days. } \\ 100 & 100 \\ 103 & 109 \\ 99 & 107\end{array}$

(c) 102 Covered with beaker, kept in dark

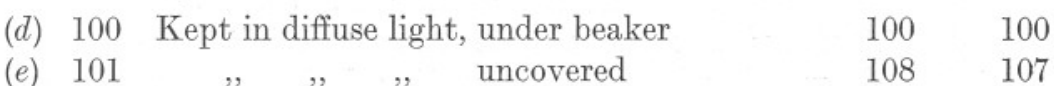

contrary, that the blue colour produced in the diphenylbenzidine reaction is extremely stable, as may be seen by inspecting Table 7 ; indeed the

* This position was slightly warmer than in the dark, in a north room. 
solution exposed to light gave a slightly more intense colour than that kept in the dark. This is beyond the range of experimental error and may be attributed to the fact that the room was somewhat warmer. Apparently the uncovered tubes absorb traces of nitrate or nitrite from the air, and though they also absorb a little water, so that the upper surface is of reduced intensity, or almost colourless, yet the absorption of nitrogen acids preponderates.

\section{Rate of the Reaction and Preparation of Permanent Colour Standards.}

Difficulty was experienced in studying the rate of the reaction owing to the fact that no substance could be found which readily matched its colour. It was however shown by comparing the intensity produced by solutions of different concentrations that even after 66 hours the reaction had not entirely ceased at room temperature. The following were examined and found not to give a match to the blue produced in the diphenylbenzidine reaction: Methyl blue, methylene blue, alizarine blue; Victoria blue, British Drug Houses, also the following five, Nile blue sulphate, water blue, aniline blue water soluble, cotton blue and thymol blue alkaline range; toluidin blue and readily soluble Berlin blue $1 \mathrm{~A}$, both Grübler; xylenol blue, Cooper Laboratory; cyanin, Metz; xylene cyanole, FF, Sandoz; also ammonia copper sulphate and the blue colour produced in the Denigès phosphate reaction. Of the oxidation reduction indicators indigo tetrasulphonate and indigo monosulphonate, Lamotte, were also tried, and the latter gave the best match of all tried, provided that comparisons were made in the diffused daylight of a greyish sky. In sunlight or with a blue sky, however, the match was not so good. As a test of the identity of the tint of the indigo monosulphonate and the blue produced in the reaction, comparisons were made in yellow, green and blue light. The values found were closely the same. It was also found that a better agreement between consecutive readings could be obtained by using a Schott and Gen green filter, VG2, $1 \mathrm{~mm}$., owing to the great sensitiveness of the eye to green light and variations in green tints. The only drawback to using indigo monosulphonate appears to be the fact that it is an oxidation-reduction indicator and liable to undergo alteration on standing. The monosulphate, however, while freely soluble in warm water, deposits when the water cools and so gives a colour which is not sufficiently intense for the stronger solutions which it may be desired to examine. It was found that an alcoholic solution was satisfactory, taking equal volumes of absolute alcohol and water, and diluting the solution then with absolute alcohol, till it was approximately the colour of that produced by $0.001 \mathrm{mg}$. of nitrate nitrogen with diphenylbenzidine. This solution was then boiled, in order that any reducing substances 
present might exert their full effect upon the colour intensity ; no change was however appreciable. On standing in a south window for four days the intensity fell off to an obvious extent, but the solution stored in the dark appeared to have remained unaltered. The solution is undoubtedly sufficiently stable for use as a standard provided it is checked against nitrate solution made up in sea-water. Figure 4 shows the course of the diphenylbenzidine reaction with a sea-water containing $72 \mathrm{mg}$. nitrate nitrogen per litre and allowed to stand at room temperature. It was compared with a saturated aqueous solution of indigo monosulphonate, and

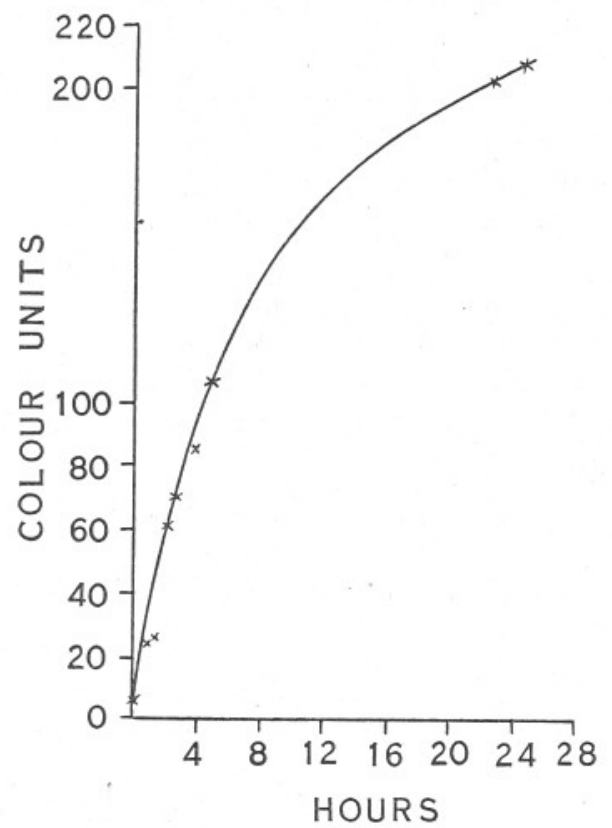

FIG. 4.-To show the course of the diphenylbenzidine reaction with sea-water containing nitrate, at about $12^{\circ} \mathrm{C}$.

allowed to stand in diffused light. The measurements were not continued after the second day, because even in a diffused light this weak aqueous solution had deteriorated somewhat. It appears obvious, however, that the increase in colour which may be obtained by allowing the reaction to stand over for another day is not compensated by the additional consumption of time or by the risk of contamination previously mentioned. Riehm (1930) recommends the preparation of colour standards by diluting the blue given by known amounts of nitrate, by the addition of sulphuric acid of the same concentration as used in the reaction, viz. the final concentration. The diluted scale is said to be stable for 48 hours at least. 


\section{SUMMARY.}

1. The diphenylbenzidine reaction of Letts and Rea has been examined and is recommended for use in sea-water ; $2.5 \mathrm{ml}$. of sea-water is mixed with $6.0 \mathrm{ml}$. of the purest strong sulphuric acid and then allowed to cool. Subsequently $1.5 \mathrm{ml}$. of a sulphuric acid solution of diphenylbenzidine is added, the concentration being $20 \mathrm{mg}$. per $100 \mathrm{ml}$. of acid. The colour should be compared, after 20-24 hours, with a standard solution made up by adding a definite quantity of nitrate to the sea-water. A blank correction should be used. Diphenylbenzidine used must be recrystallised from boiling toluene.

2. If the sulphuric acid used is found to give a blue colour with diphenylbenzidine, this may be removed, if not too intense, by warming the acid for a few minutes. With a more intense blue the nitric acid present may be eliminated by previous cautious treatment with hydrogen sulphide. Phosphoric acid may be used instead of sulphuric acid with fresh water, but not with sea-water.

3. A series of tests on the same sample of sea-water may be found to agree to within 5 per cent. With the amount used the agreement found was to less than $0 \cdot 000,01 \mathrm{mg}$. The intensity of the colour produced in the reaction when nitrate is dissolved in distilled water is increased by the addition of sodium chloride. When examined after 20 hours it is found that a 0.4 per cent solution of sodium chloride produces as much effect as a 3 per cent solution.

5. Nitrites are decomposed by the sulphuric acid in the reaction so that the full effect of nitrites present is not exerted. By cooling at once after the addition of the acid the loss is however not material, especially as the amount of nitrite in sea-water is usually far less than that of nitrate.

6. Ferric iron is found to give the reaction, but only to the extent of $1 / 20$ of that produced by nitrate nitrogen, weight for weight, and causes no error in sea-water.

7. Iodate and nitrate produce the blue colour in amounts which are proportionate to their molecular concentration. Iodide does not appear to interfere nor do arsenite or arsenate. Iodate, if present, should be removed with sodium hydrogen sulphite in very dilute solution or preferably by dilute sodium iodide, since the trace of iodine liberated does not cause appreciable interference. The iodide already in sea-water along with iodate destroys a portion of the latter in any case.

8. The colour produced in the diphenylbenzidine reaction is stable towards light and may be matched in diffused daylight from a grey sky 
with indigo monosulphonate. Comparison is carried out, for preference using a green colour filter; the Schott and Gen filter VG2 has been found suitable.

\section{REFERENCES.}

Atkins, W. R. G. 1930. Seasonal changes in the nitrite content of seawater. Journ. Mar. Biol. Assoc., N.S., 16, pp. 515-518.

Atkins, W. R. G. 1930. Seasonal variations in the phosphate and silicate content of sea-water in relation to the phytoplankton crop. Pt. V. Journ. Mar. Biol. Assoc., N.S., 16, pp. 821-852.

Atkins, W. R. G. 1932. The preparation of sulphuric acid free from nitric acid. Nature, 129, p. 98.

Bigelow, H. B., and Leslie, M. 1930. Reconnaissance of the waters and plankton of Monterey Bay, July, 1928. Bull. Museum of Comparative Zoöl. at Harvard Coll., \%0, pp. 429-581.

Binı, C. 1929. Di alcune caratteristiche del Mar Rosso sui riguardi del ciclo dell' azoto. Atti R. Accad. dei Lincei. Series 7, 9, pp. 11281133 .

Böhnecke, G., Hentschel, E., and Wattenberg, H. 1930. Über die hydrographischen, chemischen und biologischen Verhältnisse an der Meeresoberfläche zwischen Island und Grönland. Ann. d. Hydrog. usw., 58, Heft 7, pp. 233-250.

Brandt, K. 1915. Über den Nitratgehalt des Ozeanwassers und seine biologische Bedeutung. Nova Acta. Abh. der Kaiserl. Leop.-Carol. Deutschen Akad. d. Naturforscher, Bd. C, Nr. 4, pp. 1-56.

Brandt, K. 1927. Stickstoffverbindungen im Meere. 1. Wiss. Meeresuntersuch. Abt. Kiel, 20, pp. 201-292.

Brandt, K. 1929. Phosphate und Stickstoffverbindungen als Minimumstoffe für die Produktion im Meere. Rapp. et Procès-Verbaux d. Réunions. Conseil permanent internat. pour l'Exploration de la Mer, 53, pp. 5-35.

Buch, K. 1923. Methodisches über die bestimmung von stickstoffverbindungen im wasser. Havsforskningsinstitutets Skrift, Helsingfors, No. 18, pp. 1-22.

Buch, K. 1929. Über die Bestimmungen von Stickstoffverbindungen und Phosphaten im Meerwasser. See Brandt, 1929, pp. 36-52.

Cooper, L. H. N. 1932. The reduced strychnine reagent for the determination of nitrate in the sea. Jour. Mar. Biol. Assoc., N.S., 18, No. 1, pp. 161-166. 
Denigès, G. 1911. A rapid test for nitrites and nitrates in water by means of a new hydro-strychnine reagent. Bull. Soc. Chim. France, 1911, 9, pp. 544-546. Cited from J. Soc. Chem. Ind., 30, p. 827 .

Ekkert, LAd. 1925. The diphenylamine test. Pharm. Zentralhalle, 66, pp. 649-650. Cited from Chemical Abstracts.

GaD-Andresen, K. L. 1928. A method for quantitative determination of ammonia, nitrate and nitrite, together with other nitrogenous compounds, in sea-water. Cons. permanent internat. pour l'Expl. de la Mer. Publ. de Circonstance, No. 82, pp. 1-22.

GIRAL, J. 1929. Méthodes pour l'etude des phosphates et des matières azotées dans l'eau de mer. See Brandt, 1929, pp. 53-67.

Gran, H. H. 1930. The spring growth of the plankton at Moere in 1928-29 and at Lofoten in 1929 in relation to its limiting factors. Norse Videnskaps-Akad. i Oslo. 1. Mat. Naturv. Kl., No. 5, pp. 1-77.

Harvey, H. W. 1925. Oxidation in sea-water. Journ. Mar. Biol. Assoc., N.S., 13, pp. 953-969.

Harvey, H. W. 1926. Nitrate in the sea. Loc. cit., 14, pp. 71-88.

Harvey, H. W. 1928. Nitrate in the sea. II. Loc. cit., 15, pp. 183-190.

Harvey, H. W. 1929. Methods of estimating phosphates and nitrates in sea-water. See Brandt, 1929, pp. 68-74.

Hooker, S. C. 1888. Carbazol as a reagent for estimation of nitrates. Ber. d. deut. chem. Ges., 21, p. 3302. Cited.

IBAÑEZ, O. G. 1929. Determinacion del nitrogeno en sus formas amoniacal, nitroso y nitrico, en el agua de mar. Madrid, Ministerio de Fomento. Notas y résumenes, Ser. II, Nr. 36, pp. 1-24.

Issatchenko, B. 1926. Sur la nitrification dans les mers. Compt. rend. Acad. Sc. Paris, 182, p. 185.

Kehrmann, F., and Mrcewitz, St. 1912. Cause of the blue colour produced by nitrous acid and other oxidising agents in sulphuric acid solutions of diphenylamine. Ber. d. deut. chem. Ges., 45, p. 2641. Cited from J. Chem. Soc., 1912, A i, 1020.

Kolthoff, I. M., and Sarver, L. A. 1930. Properties of diphenylamine and diphenylbenzidine as oxidation-reduction indicators. J. Amer. Chem. Soc., 52, pp. 4179-4191.

Kopp, E. 1872. Diphenylamine as a reagent for the estimation of nitrites and nitrates. Ber. d. deut. chem. Ges., 5, p. 284. Cited. 
Kreps, E., and VerJbinskaya, N. 1930. Seasonal changes in the phosphate and nitrate content and in hydrogen ion concentration in the Barents Sea. J. du Conseil. Internat. pour l'Expl. de la Mer, 5, pp. 329-346.

Letrs, E. A., and ReA, F. W. 1914. An extremely delicate colorimetric method for detecting and estimating nitrates and nitrites. J. Chem. Soc., 105, pp. 1157-1161.

Lindo, D. 1888. Phenol and some allied bodies as tests for nitrites, nitrates and chlorates. Chem. News, 58, pp. 1, 15, 28. Cited.

Moberg, E. G. 1928. The interrelation between diatoms, their chemical environment, and upwelling water in the sea, off the coast of Southern California. Proc. Nat. Acad. Sci., 14, pp. 511-518.

Moberg, E. G. 1929. The phosphate, silica and fixed nitrogen content of sea-water. Proc. 3rd Pan-Pacific Science Congress, Tokyo, 1926, pp. 229-232.

OrR, A. P. 1926. The nitrite content of sea-water. Jour. Mar. Biol. Assoc., N.S., 14, pp. 55-61.

Orton, J. H. 1924. Ministry of Agric. and Fisheries Invest., Series 2, 6, No. 3, p. 166.

Rienm, H. 1930. Systematic study of the reaction of diphenylamine sulphate with nitrates in the presence of chlorides, especially with respect to the determination of nitrates in soils. Z. anal. Chem., 81, pp. 353-377.

Rienм, H. 1930. Systematic study of the reaction of diphenylbenzidine in sulphuric acid solution with nitrates in the presence of chloride. Z. anal. Chem., 81, pp. 439-447. Cited.

Ruud, J. T. 1930. Nitrates and phosphates in the Southern Seas. J. du Cons. Internat. pour l'Expl. de la Mer, 5, pp. 347-360.

Sмrth, L. 1917. The use of diphenylamine and diphenylbenzidine for colorimetric estimations. Zeitschr. f. anal. Chem., 56, pp. 28-42. Cited from J. Chem. Soc., 112, ii, p. 217.

Snell, F. D. 1921. Colorimetric analysis. New York.

Sprengel, H. 1864. Use of phenolsulphonic acid for estimation of nitrate. Pogg. Ann., 121, p. 188. Cited.

Sund, O. 1929. The determination of nitrates in sea-water. See Brandt, 1929, pp. 80-89.

Thompson, T. C., and Johnson, M. W. 1930. The sea-water at the Puget Sound Biological Station from September 1928 to September 1929. Publ. Puget Sound Biol. Sta., y, pp. 345-368. 
Thomsen, Helge. 1931. Nitrate and phosphate contents of Mediterranean water. Report on the Danish Oceanographical Expeditions, 1908-1910, to the Mediterranean and adjacent seas. 3, Pt. 6, pp. 1-14.

Trllmans, J. 1910. Detection and estimation of nitric acid in milk by diphenylamine-sulphuric acid. Z. Nahr. Genussm., 20, p. 676. Cited from J. Soc. Chem. Ind., 1911, 30, p. 44.

Tillmans, J., and Sutthoff, W. 1911. Method of detecting and determining nitric and nitrous acids in water. Z. anal. Chem., 1911, 50, pp. 473-495. Cited from J. Soc. Chem. Ind., 1911, 30, p. 918.

Tschigirine, N., and Daniltchenko, P. 1930. De l'azote et ses composés dans le mer Noire. Trav. de la Stat. Biol. de Sébastopol., 2, pp. 1-16.

Wattenberg, H. 1929. Die Phosphat- und Nitrat- Untersuchungen der Deutschen Atlantischen Expedition auf V.S. Metcor. See Brandt, 1929, pp. 90-94.

Wieland, H. 1913. Über den Mechanismus der blauen Farbreaktion des Diphenylamins. XVI. Über ditertiäre Hydrazine. Ber. d. deut. chem. Ges., 46 (3), pp. 3296-3303.

Winkler, L. W. 1916. Der Jodid- und Jodat- Iongehalt des Meerwassers. Z. f. angew. Chem., 29 (1), pp. 205-207.

Yoe, J. H. 1928. Photometric chemical analysis. Vol. 1, p. 316. New York. 